\title{
Vegetation responses to 2 brush management practices in South Texas
}

\author{
JOSEPH A. BOZZO, SAMUEL L. BEASOM, AND TIMOTHY E. FULBRIGHT
}

Authors are graduate research fellow, director, and associate professor, Caesar Kleberg Wildlife Research Institute, Campus Box 218, Texas A\&I University, Kingsville 78363.

\begin{abstract}
Brush management for improving wildlife habitat in South Texas is important because of the economic value of wildlife. We determined vegetation responses to (1) roller chopping of guajillo (A cacia berlandieri Benth.)-blackbrush acacia (A. rigidula Benth.)dominated rangeland and (2) heavy discing of whitebrush (Aloysia lycioides Cham.)-dominated rangeland to improve white-tailed deer (Odocolleus virginianus Raf.) habitat. Canopy cover of vegetation was estimated seasonally during August 1988 to April 1990. Both treatments reduced brush canopy cover, but herbaceous response depended on rainfall. Mean herbaceous cover was 65 and $136 \%$ higher on roller chopped sites than on untreated sites when averaged across all sampling dates. Heavy discing reduced relative canopy cover of whitebrush but increased cover of spiny hackberry (Celtis pallida Torr.), an important browse species. Forb species richness was higher on roller chopped and disced sites than on untreated sites, but species diversity was similar. Because herbaceous response to brush removal may depend on rainfall, other factors such as effects on browse availability and nutritional quality may need to be considered when planning brush management strategies to improve white-tailed deer habitat.
\end{abstract}

Key Words: disc, habitat, Odocoileus virginianus, roller chopper, white-tailed deer

Research was funded by the Enron Corporation. Tom Martin, Jr., provided the research area.

Manuscript accepted 22 July 1991.
Brush provides browse and cover for white-tailed deer (Odocoileus virginianus Raf.). Browse is a major component of deer diets in the western Rio Grande Plain of Texas (Arnold and Drawe 1979, Varner and Blankenship 1987). However, forbs compose a high percentage of deer diets when available (Chamrad and Box 1968). Dense stands of brush may compete with herbaceous vegetation, reducing forb production.

Roller chopping is a relatively inexpensive brush management technique whereby a crawler-type tractor pulls a drum fitted with blades (Doerr et al. 1986). Most south Texas woody plants sprout prolifically after top removal (Powell and Box 1967). Regrowth following top removal is temporarily more accessible and more nutritious than browse from untreated plants (Powell and Box 1966, Everitt 1983). Reynolds et al. (1989) reported that crude protein and in vitro organic matter digestibility of guajillo (Acacia berlandieri Benth.) leaves from regrowth was higher than that of untreated plants for 6 months after roller chopping. Roller chopping did not increase crude protein content or in vitro organic matter digestibility of blackbrush acacia ( $A$. rigidula Benth.) leaves.

Dense whitebrush (Aloysia lycioldes Cham.) communities receive little use by white-tailed deer relative to other plant communities with similar canopy cover (Steuter and Wright 1980). Reduction of whitebrush should enhance herbaceous forage production because the shrub occupies fertile soils (Scifres 1980). Discing kills whitebrush because it is shallow rooted. Soil disturbance resulting from

JOURNAL OF RANGE MANAGEMENT 45(2), March 1992 
discing rangeland may result in increased abundance of forbs important to wildlife (Buckner and Landers 1979, Webb and Guthery 1983, Nurdin and Fulbright 1988).

We evaluated 2 management practices for improving habitat for white-tailed deer based on the predictions that (1) roller chopping of dense brush stands dominated by guajillo and blackbrush acacia would increase forb canopy cover, species richness, and diversity of herbaceous vegetation; and (2) discing of dense brush stands dominated by whitebrush would reduce canopy cover of whitebrush while maintaining cover of more deeply rooted browse plants and increasing forb canopy cover, species richness, and diversity of herbaceous vegetation. We determined vegetation responses to roller chopping and discing to test these predictions.

\section{Study Area}

The study was conducted on the 7,285-ha La Campana Ranch in McMullen and Duval counties, Texas. Climate of the area is subtropical with hot summers and mild winters. The average annual temperature in Freer, Texas ( $35 \mathrm{~km}$ southwest of the study area), is $21.6^{\circ} \mathrm{C}$, with mean January and July temperatures of 12.7 and $28.8^{\circ} \mathrm{C}$ (Nat. Fibers Info. Cent. 1987). The normal frost-free period extends from 16 February to 11 December, with an average growing season of 298 days. Average annual rainfall (1959-1989) recorded at the ranch is $70.5 \mathrm{~cm}$ (J. Locke, La Campana Ranch, pers. comm.). Rainfall is highly variable among years and is bimodal with peaks in May and September. Rainfall during the study was 55 and $47 \%$ of the annual average for 1988 and 1989 , respectively; however, from January to April 1990 it was $169 \%$ of average (Fig. 1).

Major brush species present on the study area included blackbrush acacia, ceniza [ Leucophyllum frutescens (Berl.) I.M. Johnston], guajillo, guayacan [Porlieria angustifolia Engelm. (Gray)], lotebrush [Zizyphus obtusifolia (T. \& G.) Gray], mesquite (Prosopis glandulosa Torr.), spiny hackberry (Celtis pallida Torr.), and whitebrush. Curly mesquite [Hilaria belangeri Steud.) Nash] and red grama (Bouteloua trifida Thurb.) were the major grasses.

Soils at the study area were of the Hidalgo-Pettus-Olmos association (Soil Conserv. Serv. 1985). The Olmos soils are very gra velly loam, carbonitic, hyperthermic, shallow Petrocalcic Calciustolls and the Pettus soils are sandy clay loam, hyperthermic, shallow Typic Calciustols (Minzenmayer 1979). The Hidalgo soils are fine sandy loam (Soil Conserv. Serv. 1985).

The estimated white-tailed deer density was $8.6 \mathrm{~km}^{-2}$ in 1988 and $8.8 \mathrm{~km}^{-2}$ in 1989. Estimates were based on annual helicopter counts in October. Cattle stocking varied but averaged 0.08 animal unit $\mathrm{ha}^{-1} \mathrm{year}^{-1}$. The ranch was continuously grazed and cattle ranged freely among pastures. Cattle use of study sites was infrequent and deer browsing intensity appeared low.

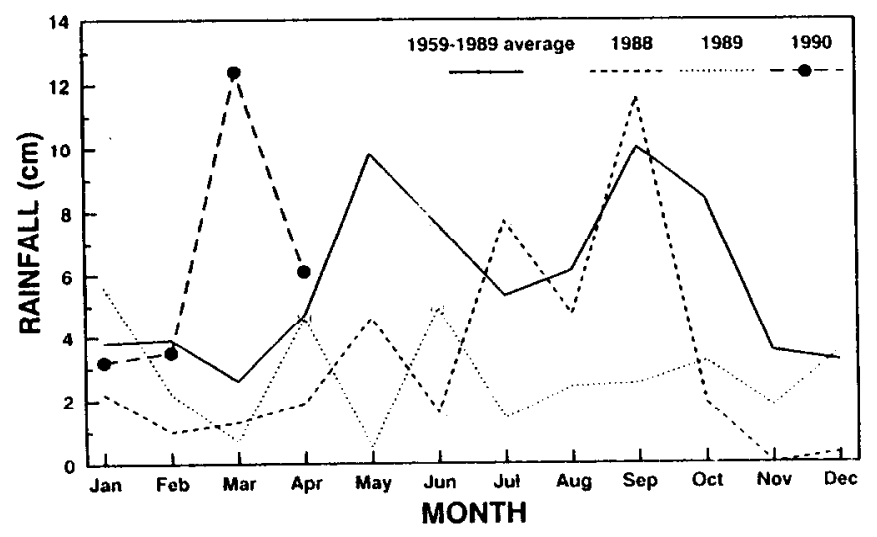

Fig. 1. Monthly rainfall for 1988 , 1989, January to April 1990, and 29-year average (1959-1989) for La Campana Ranch, McMullen and Duval counties, Texas.

\section{Methods}

Three separate sites, dominated by guajillo-blackbrush acacia and ranging from 30 to $125 \mathrm{ha}$, were roller chopped with 1 pass during July 1988 in a strip pattern using a $6.4-\mathrm{m}$-wide, $27,216-\mathrm{kg}$ roller-chopper drum pulled behind a crawler tractor. The number of strips per site ranged from 3 to 5 and their widths totaled about $20 \%$ of each site. An additional $20 \%$ of each site was treated in a similar manner during June 1989. Three separate sites dominated by whitebrush and ranging from 16 to 41 ha in size were disced with 1 pass in strips during July 1988 using a 3.7-m-wide Steiger disc with $91-\mathrm{cm}$ blades. Disced strips comprised about $20 \%$ of each site. Adjacent strips comprising an additional $20 \%$ of each site were disced during May 1989.

Percent canopy cover of woody species was estimated by the line-intercept method along 10,15-m transects in treated strips in each treated site and ten $15-\mathrm{m}$ transects in the untreated portions (Canfield 1941). Transects were placed by stratified random sampling with a baseline (Knight 1978 in Chambers and Brown 1983). Percent canopy coverage and rooted frequency of herbaceous plants were estimated in $20 \times 50-\mathrm{cm}$ quadrats placed at 5-m intervals along each transect (Daubenmire 1959). Canopy cover was estimated in 30 quadrats treatment ${ }^{-1}$ site $^{-1}$. Data for each site were collected seasonally (winter $=$ January-March, spring = AprilJune, summer $=$ July-September, and fall = October-December).

Analysis of variance in a randomized, complete-block design with replicated sites as experimental units, was used to test for treatment effects on vegetation. Tukey's studentized range test was used to separate treatment means at the 0.05 significance level. Forb frequencies were compared using Kruskal-Wallis tests (Bartz 1981). Plant cover was considered as a measure of abundance to

Table 1. Mean canopy cover (\%) of blackbrush acacia, guajillo, and total brush on untreated sites (Untr) and 3 adjacent sites roller-chopped in summer 1988 (T88) or summer 1989 (T89) on La Campana Ranch, McMullen and Duval counties, Texas, summer $1988-$ spring 1990.

\begin{tabular}{|c|c|c|c|c|c|c|c|c|c|}
\hline \multirow[b]{2}{*}{ Season } & \multicolumn{3}{|c|}{ Blackbrush acacia } & \multicolumn{3}{|c|}{ Guajillo } & \multicolumn{3}{|c|}{ Total Brush } \\
\hline & Untr & $\mathrm{T} 88$ & T89 & Untr & $\mathrm{T} 88$ & T89 & Untr & $\mathrm{T} 88$ & T89 \\
\hline & $\ldots \ldots$ & & & & $-\%=$ & ---0 & $-\ldots$ & $\ldots$ & $-\ldots$ \\
\hline Summer 1988 & $18.5 \mathrm{a}$ & $2.8 \mathrm{~b}$ & - & $49.9 \mathrm{a}$ & $2.6 \mathrm{~b}$ & - & $80.9 \mathrm{a}$ & $8.4 b$ & - \\
\hline Fall 1988 & $21.3 \mathrm{a}$ & $6.5 b$ & - & $47.4 \mathrm{a}$ & $16.2 \mathrm{~b}$ & - & $79.1 \mathrm{a}$ & $27.9 b$ & - \\
\hline Winter 1989 & $24.9 a$ & $5.8 \mathrm{~b}$ & - & $38.6 a$ & $11.0 \mathrm{~b}$ & - & $68.6 a$ & $18.4 b$ & - \\
\hline Spring 1989 & $22.7 a$ & $8.0 \mathrm{a}$ & - & $47.1 \mathrm{a}$ & $17.6 \mathrm{a}$ & - & $77.3 a$ & $29.2 \mathrm{~b}$ & - \\
\hline Summer 1989 & $16.7 \mathrm{a}$ & $8.6 \mathrm{ab}$ & $3.2 b$ & $49.4 a$ & $14.7 \mathrm{~b}$ & $3.7 \mathrm{~b}$ & $77.0 \mathrm{a}$ & $26.2 \mathrm{~b}$ & $3.2 \mathrm{c}$ \\
\hline Fall 1989 & $24.4 \mathrm{a}$ & $8.1 \mathrm{a}$ & $4.4 a$ & $47.3 \mathrm{a}$ & $10.7 b$ & $8.0 \mathrm{~b}$ & $75.1 \mathrm{a}$ & $22.2 \mathrm{~b}$ & $15.2 \mathrm{~b}$ \\
\hline Winter 1990 & $25.9 \mathrm{a}$ & $5.2 b$ & $2.5 b$ & $44.0 \mathrm{a}$ & $12.2 b$ & $5.7 \mathrm{~b}$ & $74.4 \mathrm{a}$ & $21.1 \mathrm{~b}$ & $10.0 c$ \\
\hline Spring 1990 & $28.7 a$ & $5.7 \mathrm{~b}$ & $1.8 \mathrm{~b}$ & $45.2 \mathrm{a}$ & $17.7 \mathrm{~b}$ & $15.5 b$ & $79.4 a$ & $28.4 \mathrm{~b}$ & $22.1 \mathrm{c}$ \\
\hline
\end{tabular}

Means within a row and species followed by the same letter do not differ significantly $(P>0.05)$ according to Tukey's studentized range test. 
Table 2. Mean shrub richness and diversity on 3 untreated sites (Untr) and 3 adjacent sites roller chopped or disced in 1988 (T88) or 1989 (T89) on La Campana Ranch, McMullen and Duval counties, Texas, summer 1988-spring 1990.

\begin{tabular}{|c|c|c|c|c|c|c|c|c|c|c|c|c|}
\hline \multirow[b]{3}{*}{ Season } & \multicolumn{6}{|c|}{ Roller chopped } & \multicolumn{6}{|c|}{ Disced } \\
\hline & \multicolumn{3}{|c|}{ Diversity } & \multicolumn{3}{|c|}{ Shrub richness } & \multicolumn{3}{|c|}{ Diversity } & \multicolumn{3}{|c|}{ Shrub richness } \\
\hline & Untr & T88 & T89 & Untr & $\mathrm{T} 88$ & T89 & Untr & T88 & T89 & Untr & T88 & T89 \\
\hline Summer 1988 & $2.5 a$ & $2.2 \mathrm{a}$ & - & $16.3 \mathrm{a}$ & $10.3 \mathrm{a}$ & - & $1.3 \mathrm{a}$ & $2.0 \mathrm{a}$ & 一 & $9.7 \mathrm{a}$ & $6.3 \mathrm{a}$ & - \\
\hline Fall 1988 & $2.4 a$ & $1.9 a$ & - & $15.3 \mathrm{a}$ & $10.0 \mathrm{a}$ & - & $1.3 \mathrm{a}$ & $1.3 \mathrm{a}$ & 一 & $8.7 \mathrm{a}$ & $5.0 \mathrm{a}$ & - \\
\hline Winter 1989 & $2.2 a$ & $1.6 \mathrm{a}$ & - & $13.0 \mathrm{a}$ & $8.7 \mathrm{a}$ & - & $1.2 \mathrm{a}$ & $1.0 \mathrm{a}$ & - & $9.3 a$ & $3.3 \mathrm{~b}$ & - \\
\hline Spring 1989 & $2.1 \mathrm{a}$ & $1.7 \mathrm{a}$ & - & $13.3 \mathrm{a}$ & $11.0 \mathrm{a}$ & - & $0.7 \mathrm{~b}$ & $1.6 \mathrm{a}$ & - & $5.7 a$ & $6.3 a$ & - \\
\hline Summer 1989 & $2.2 \mathrm{a}$ & $1.9 \mathrm{a}$ & $2.1 \mathrm{a}$ & $15.3 \mathrm{a}$ & $12.3 \mathrm{a}$ & $8.7 \mathrm{a}$ & $0.6 \mathrm{a}$ & $1.5 \mathrm{a}$ & $1.2 \mathrm{a}$ & $6.3 \mathrm{a}$ & $6.0 \mathrm{a}$ & $3.0 \mathrm{a}$ \\
\hline Fall 1989 & $2.0 \mathrm{a}$ & $2.0 \mathrm{a}$ & $1.6 \mathrm{a}$ & $14.0 \mathrm{a}$ & $12.3 \mathrm{a}$ & $7.3 b$ & $0.5 b$ & $1.3 \mathrm{a}$ & $1.7 \mathrm{a}$ & $5.3 a$ & $7.0 \mathrm{a}$ & $4.0 \mathrm{a}$ \\
\hline Winter 1990 & $2.2 \mathrm{a}$ & $1.8 \mathrm{a}$ & $1.7 \mathrm{a}$ & $16.7 a$ & $12.3 \mathrm{~b}$ & $8.3 b$ & $0.5 a$ & $1.3 \mathrm{a}$ & $1.2 \mathrm{a}$ & $4.3 a$ & $5.0 \mathrm{a}$ & $3.3 \mathrm{a}$ \\
\hline Spring 1990 & $2.1 \mathrm{a}$ & $1.8 \mathrm{~b}$ & $1.7 \mathrm{~b}$ & $14.7 \mathrm{a}$ & $10.0 \mathrm{a}$ & $10.3 \mathrm{a}$ & $0.5 a$ & $1.4 \mathrm{a}$ & $1.2 \mathrm{a}$ & $6.0 \mathrm{a}$ & $4.7 \mathrm{a}$ & $3.7 \mathrm{a}$ \\
\hline
\end{tabular}

Richness and diversity means within a row and treatment practice followed by the same letter do no differ significantly $(P>0.05)$ according to Tukey's studentized range test.

calculate Shannon's index (Pielou 1977) and comparisons were made between treatments and controls at the 0.05 level. Plant nomenclature follows Gould (1975).

\section{Results and Discussion}

\section{Shrub Response to Roller Chopping}

Total brush cover was reduced by $90 \%$ and $96 \%$ immediately following roller chopping during summer 1988 and 1989, respectively (Table 1). Brush canopy cover increased considerably during the 3 months following treatment in 1988 and 1989 but remained lower than untreated sites during the 2 years of study.

Diversity of woody plants, as determined by Shannon's Index, was generally similar between treatments and untreated sites; however, treatment values were lower in spring 1990 (Table 2). Fulbright and Beasom (1987) reported similar results on sites 30 years after roller chopping. Woody species richness was similar in rollerchopped and untreated sites except in fall 1989 and winter 1990 when richness was greater in untreated sites. Naderman (1979) reported little loss of woody species 2.5 years after roller chopping.

\section{Herbaceous Response to Roller Chopping}

Total grass cover was similar on roller-chopped and untreated sites except in summer 1989 when canopy cover was greater in the 1988 treatment (Table 3). In comparison, Naderman (1979) reported both an increase and a decrease, on separate sites, of grass cover 2.5 years after roller chopping, whereas Box and Powell (1965) found no difference in grass cover 1 year following roller chopping, but an increase 2 years after treatment.

Total forb canopy cover was higher on 1988 treated than untreated sites in summer 1989 (Table 3). Following summer 1989, forb cover was highest on the 1989 treated sites and greater than in untreated sites in winter and spring 1990 , following periods of high rainfall. Contrasting results with regard to forb production following brush management have been reported in previous studies.
Both Naderman (1979) and Powell and Box (1967) described no increase in forb cover following roller chopping. However, Rollins (1983) found increased forb production following chaining.

In winter 1990, canopy cover of lazydaisy (Aphanostephus sp.), an important deer food (Nelle 1984), was higher on sites treated in $1989(3.5 \pm 1.2 \%)(\bar{x} \pm \mathrm{SD})$, compared to both untreated sites $(0.2$ $\pm 0.1 \%)$ and sites treated in $1988(0.8 \pm 1.5 \%)$. Cover of pellitory (Parietaria pennsylvanica Muhl.) was higher in the 1989 treatment $(12.8 \pm 5.4 \%)$ and the 1988 treatment $(9.6 \pm 6.3 \%)$ than the untreated (4.2 $\pm 5.3 \%$ ) in spring 1990. All other forbs had similar canopy cover among treatments in each season. Absolute frequency of lazydaisy and tallowweed (Plantago rhodosperma Dcne.) also important to deer (Nelle 1984), was greater in the 1989 treatment compared with the untreated and 1988 treatment in winter 1990 . Frequency of other forbs was similar on treated and untreated sites (data not shown).

The highest mean forb richness for all treatments occurred in spring 1990 in response to above-average rainfall (Table 4). The 1988 treatment had the highest single-season average ( 41 species) in spring 1990. The lowest average (4 species) was on sites treated in 1988 during summer 1988 , immediately following treatment.

Herbaceous plant diversity was similar in treated and untreated sites, except in summer 1989 when both the 1988 and 1989 treatments had higher diversity than the untreated, and spring 1990 when the 1988 treatment had higher diversity than the untreated (Table 4). The highest diversity occurred during winter and spring 1990 when greater rainfall occurred.

Lack of herbaceous response to treatments before winter 1990 probably can be attributed to low rainfall. Only after adequate rainfall in December 1989-April 1990 were increases in total herbaceous canopy cover on treated sites documented.

\section{Shrub Response to Discing}

Total brush cover was initially reduced by an average of $89 \%$ in

Table 3. Mean canopy cover (\%) of total grass, total forbs, and total herbaceous plants on 3 untreated sites (Untr) and 3 adjacent sites roller-chopped in summer 1988 (T88) or summer 1989 (T89) on La Campana Ranch, McMullen, and Duval counties, Texas, summer 1988-spring 1990.

\begin{tabular}{|c|c|c|c|c|c|c|c|c|c|}
\hline \multirow[b]{2}{*}{ Season } & \multicolumn{3}{|c|}{ Total grass } & \multicolumn{3}{|c|}{ Total forbs } & \multicolumn{3}{|c|}{ Total herbaceous } \\
\hline & Untr & T88 & T89 & Untr & T88 & T89 & Untr & T88 & T89 \\
\hline &.- & 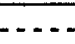 & & -- & $-\%-$ & $\cdots$ & $\cdots-$ & --- & $\cdots$ \\
\hline Summer 1988 & $2.4 \mathrm{a}$ & $2.0 \mathrm{a}$ & _- & $1.2 \mathrm{a}$ & $0.4 a$ & - & $3.6 \mathrm{a}$ & $2.4 \mathrm{a}$ & - \\
\hline Fall 1988 & $8.5 a$ & $8.1 \mathrm{a}$ & - & $4.2 a$ & $6.1 \mathrm{a}$ & - & $12.6 \mathrm{a}$ & $14.3 \mathrm{a}$ & - \\
\hline Winter 1989 & $3.0 \mathrm{a}$ & $6.7 \mathrm{a}$ & $\ldots$ & $4.6 \mathrm{a}$ & $8.2 \mathrm{a}$ & - & $7.7 \mathrm{a}$ & $14.9 \mathrm{a}$ & - \\
\hline Spring 1989 & $5.4 a$ & $12.3 \mathrm{a}$ & - & $4.7 \mathrm{a}$ & $7.2 \mathrm{a}$ & - & $10.1 \mathrm{a}$ & $19.5 a$ & - \\
\hline Summer 1989 & $5.2 b$ & $14.6 \mathrm{a}$ & $6.3 b$ & $3.4 b$ & $8.1 a$ & $2.3 \mathrm{~b}$ & $8.6 \mathrm{~b}$ & $22.7 \mathrm{a}$ & $8.5 b$ \\
\hline Fall 1989 & $1.4 \mathrm{a}$ & $7.6 \mathrm{a}$ & $3.6 \mathrm{a}$ & $1.3 \mathrm{a}$ & $2.3 \mathrm{a}$ & $2.6 \mathrm{a}$ & $2.7 \mathrm{~b}$ & $10.0 \mathrm{a}$ & $6.2 \mathrm{ab}$ \\
\hline Winter 1990 & $1.2 \mathrm{a}$ & $4.0 \mathrm{a}$ & $3.3 \mathrm{a}$ & $14.9 \mathrm{~b}$ & $24.4 \mathrm{ab}$ & $35.6 \mathrm{a}$ & $16.1 \mathrm{~b}$ & $28.3 \mathrm{ab}$ & $38.9 \mathrm{a}$ \\
\hline Spring 1990 & $2.1 \mathrm{a}$ & $8.7 \mathrm{a}$ & $3.9 a$ & $47.2 \mathrm{c}$ & $61.4 b$ & $72.9 a$ & $49.3 \mathrm{~b}$ & $70.1 \mathrm{a}$ & $76.8 \mathrm{a}$ \\
\hline
\end{tabular}

Means within a row and plant class followed by the same letter do not differ significantly $(P>0.05)$ according to Tukey's studentized range test. 
Table 4. Mean forb and herbaceous plant diversity on 3 untreated sites (Untr) and 3 adjacent sites roller chopped or disced in 1988 (T88) or 1989 (T89) on La Campana Ranch, McMullen and Duval counties, Texas, summer 1989-spring 1990.

\begin{tabular}{|c|c|c|c|c|c|c|c|c|c|c|c|c|}
\hline \multirow[b]{3}{*}{ Season } & \multicolumn{6}{|c|}{ Roller chopped } & \multicolumn{6}{|c|}{ Disced } \\
\hline & \multicolumn{3}{|c|}{ Forb richness } & \multicolumn{3}{|c|}{ Diversity } & \multicolumn{3}{|c|}{ Forb richness } & \multicolumn{3}{|c|}{ Diversity } \\
\hline & Untr & $\mathrm{T} 88$ & $\mathrm{~T} 89$ & Untr & $\mathrm{T} 88$ & T89 & Untr & $\mathrm{T} 88$ & T89 & Untr & $\mathrm{T} 88$ & T89 \\
\hline Summer 1988 & $5 \mathbf{a}$ & $4 a$ & - & $2.0 \mathrm{a}$ & $2.4 a$ & - & $4 a$ & $1 a$ & - & $1.7 \mathrm{a}$ & $0.5 a$ & - \\
\hline Fall 1988 & $7 a$ & $11 a$ & - & $2.7 \mathrm{a}$ & $3.1 \mathrm{a}$ & - & $2 b$ & $6 a$ & - & $2.2 \mathrm{a}$ & $2.4 a$ & 一 \\
\hline Winter 1989 & $12 \mathrm{a}$ & $13 \mathrm{a}$ & - & $3.3 a$ & $3.3 \mathrm{a}$ & - & $9 a$ & $11 \mathrm{a}$ & - & $2.5 \mathrm{a}$ & $3.3 \mathrm{a}$ & - \\
\hline Spring 1989 & $10 a$ & $12 \mathrm{a}$ & - & $3.0 \mathrm{a}$ & $3.4 \mathrm{a}$ & - & la & $12 b$ & - & $1.8 \mathrm{~b}$ & $3.5 \mathrm{a}$ & 一 \\
\hline Summer 1989 & $7 \mathbf{a}$ & $9 a$ & $7 \mathrm{a}$ & $2.7 \mathrm{~b}$ & $3.1 \mathrm{a}$ & $2.9 \mathrm{a}$ & lb & $9 \mathbf{a}$ & $1 \mathbf{b}$ & $1.7 \mathrm{a}$ & $3.2 \mathrm{a}$ & 1.1a \\
\hline Fall 1989 & $5 a$ & $6 a$ & $6 a$ & $2.5 \mathrm{a}$ & $2.4 a$ & $2.9 \mathrm{a}$ & $2 b$ & $6 a$ & $\mathbf{3 b}$ & $1.7 \mathrm{a}$ & $2.7 \mathrm{a}$ & $2.0 \mathrm{a}$ \\
\hline Winter 1990 & $28 \mathrm{a}$ & $34 a$ & $34 a$ & $4.1 \mathrm{a}$ & $4.4 \mathrm{a}$ & $4.3 \mathrm{a}$ & $21 a$ & $25 \mathrm{a}$ & $19 a$ & $3.3 \mathrm{a}$ & $3.8 \mathrm{a}$ & 3.1a \\
\hline Spring 1990 & $35 \mathbf{a}$ & $41 a$ & $38 a$ & $4.2 b$ & $4.4 a$ & $4.1 \mathrm{~b}$ & $16 a$ & $22 a$ & $15 a$ & $2.4 \mathrm{a}$ & $3.2 \mathrm{a}$ & $2.7 \mathrm{a}$ \\
\hline
\end{tabular}

Richness and diversity means within a row and treatment practice followed by the same letter do not significantly $(P>0.05)$ according to Tukey's studentized range test.

the 1988 treatments and $98 \%$ in the 1989 treatments. Effectiveness of the 1989 treatments may have been increased by the use of newly sharpened disc blades. Total brush cover remained lower in disced sites than in untreated sites during the 2 years of study (Table 5). In strips treated in 1988, whitebrush cover increased from $0.2 \pm 0.1 \%$ immediately following treatment to $5.5 \pm 1.7 \%$ by spring 1990,21 months after treatment.

Spiny hackberry canopy cover was reduced following the 1988 treatment (Table 5). However, spiny hackberry canopy cover was similar in treatments and controls during each of the last 5 sampling dates. Spiny hackberry is an invader following brush treatment (Scifres et al. 1976, Drawe 1977) and may increase (Box and Powell 1965). Because spiny hackberry is an important wildlife plant (Graham 1982, Nelle 1984, Guthery 1986), its presence should benefit wildlife populations.

Canopy cover of guayacan, an evergreen shrub highly preferred by white-tailed deer (Nelle 1984, Varner and Blankenship 1987), was similar between treated and untreated sites following the 1988 treatment, except in winter 1989 when the 1988 treatment had lower canopy cover (Table 5). Discing in 1989 reduced guayacan canopy cover during summer and fall 1989 and in winter 1990.

Shrub diversity was similar in treated and untreated sites, except in spring 1989, when areas disced in 1988 had higher diversity than the untreated, and in fall 1989, when discing in both years increased diversity relative to the untreated (Table 2). Higher diversity can be attributed to a more even distribution of cover among brush species following treatment. Whitebrush comprised $92 \%$ of all brush canopy cover in untreated sites averaged over all seasons, whereas it contributed only 44 and $23 \%$ in the areas treated in 1988 and 1989. Woody species richness was similar in disced and untreated sites except in winter 1989 when richness was greater in untreated sites. Drawe (1977) reported no change in brush composition following discing of a mixed brush community where pretreatment dominant brush species were capable of rapid reinvasions. Mon- temayor et al. (1991) found brush species richness and diversity were similar on disced and untreated areas 10 years after treatment.

\section{Herbaceous Response to Discing}

Total grass cover in spring 1989 was reduced by discing in 1988 (Table 6). The 1989 discing reduced grass canopy cover in summer 1989 and winter 1990 . Forb canopy cover was greater in disced than untreated strips in spring and summer 1989. Webb and Guthery (1983) found similar reductions in grass cover following spring discing treatments, but their findings suggested that individual forbs may increase. In another study, 1-pass discing did not increase annual and perennial grasses or forbs, but annual forb cover increased following the greater soil disturbance of 3-pass discing (Nurdin and Fulbright 1988). Drawe (1977) recorded a 5 -fold increase in herbaceous production following stack and discing treatments.

In winter 1990, canopy cover of southern pepperweed (Lepidium austrinum Small) was greater in the 1989 treatment (8.4 \pm $3.6 \%)$ than in untreated sites $(2.1 \pm 3.0 \%)$ and the 1988 treatment $(0.3 \pm 0.1 \%)$. However, canopy cover of lazydaisy and tallowweed was higher on the untreated than in the 1989 treatment, but similar to the 1988 treatment (data not shown). In spring 1990, canopy cover of lazydaisy $(29.6 \pm 5.3 \%)$ and southern pepperweed $(22.2 \pm$ $3.7 \%$ ) was higher in the 1988 treatment than both the untreated (11.1 \pm 2.3 and $3.4 \pm 3.6 \%$, respectively) and 1989 treatment (5.7 \pm 4.6 and $6.4 \pm 4.1 \%$, respectively). Absolute frequency of forbs was similar between treated and untreated sites (data not shown), except in winter 1990 when absolute frequency of southern pepperweed as greater in the 1989 treatment $(8.4 \pm 1.5 \%)$ compared to the untreated $(2.1 \pm 3.8 \%)$.

The greatest mean forb richness occurred in winter 1990 (Table 4). Richness of forbs was highest on sites treated in 1988 (25 species) in winter 1990. Lowest richness (1 species) occurred in untreated sites in spring and summer 1989 , and in each treated site

Table 5. Mean canopy cover (\%) of spiny hackberry, whitebrush, guayacan, and total brush on 3 untreated sites (Untr) and 3 adjacent sites disced in spring 1988 (T88) and spring 1989 (T89) on La Campana Ranch, McMullen and Duval counties, Texas, summer 1988 -spring 1990.

\begin{tabular}{|c|c|c|c|c|c|c|c|c|c|c|c|c|}
\hline \multirow[b]{2}{*}{ Season } & \multicolumn{3}{|c|}{ Spiny hackberry } & \multicolumn{3}{|c|}{ Whitebrush } & \multicolumn{3}{|c|}{ Guayacan } & \multicolumn{3}{|c|}{ Total brush } \\
\hline & Untr & $\mathrm{T} 88$ & T89 & Untr & T88 & T89 & Untr & T88 & T89 & Untr & $\mathrm{T} 88$ & T89 \\
\hline & & & & & & & - & & & - & 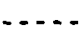 & . \\
\hline Summer 1988 & $3.9 \mathrm{a}$ & $0.6 \mathrm{~b}$ & - & $56.6 \mathrm{a}$ & $0.2 \mathrm{a}$ & - & $2.5 \mathrm{a}$ & $0.1 \mathrm{a}$ & - & $68.9 \mathrm{a}$ & $1.9 b$ & - \\
\hline Fall 1988 & $6.4 a$ & $2.9 \mathrm{a}$ & - & $66.2 \mathrm{a}$ & $3.5 \mathrm{a}$ & - & $4.2 \mathrm{a}$ & $0.1 \mathrm{a}$ & - & $76.1 \mathrm{a}$ & $8.3 b$ & - \\
\hline Winter 1989 & $3.7 \mathrm{a}$ & $2.6 b$ & - & $58.3 \mathrm{a}$ & $3.2 \mathrm{a}$ & - & $3.3 \mathrm{a}$ & $0.0 \mathrm{~b}$ & - & $70.4 a$ & $6.5 b$ & - \\
\hline Spring 1989 & $2.8 \mathrm{a}$ & $3.9 \mathrm{a}$ & - & $73.4 \mathrm{a}$ & $3.9 b$ & - & $2.4 a$ & $0.1 \mathrm{a}$ & - & $77.0 \mathrm{a}$ & $9.1 \mathrm{~b}$ & - \\
\hline Summer 1989 & $2.5 \mathrm{a}$ & $5.7 \mathrm{a}$ & $0.2 \mathrm{a}$ & $75.5 \mathrm{a}$ & $2.8 \mathrm{~b}$ & $0.1 \mathrm{~b}$ & $2.3 a$ & $0.1 b$ & $0.1 \mathrm{~b}$ & $79.2 a$ & $9.9 b$ & $0.5 \mathrm{c}$ \\
\hline Fall 1989 & $1.2 \mathrm{a}$ & $5.3 \mathrm{a}$ & $0.5 a$ & $80.1 \mathrm{a}$ & $5.4 \mathrm{~b}$ & $0.2 \mathrm{~b}$ & $3.1 \mathrm{a}$ & $0.2 b$ & $0.2 \mathrm{~b}$ & $82.8 \mathrm{a}$ & $11.6 \mathrm{~b}$ & $1.4 \mathrm{c}$ \\
\hline Winter 1990 & $0.8 \mathrm{a}$ & $3.4 \mathrm{a}$ & $0.3 a$ & $68.1 \mathrm{a}$ & $6.8 \mathrm{~b}$ & $0.3 b$ & $2.4 \mathrm{a}$ & $0.1 b$ & $0.1 b$ & $70.8 \mathrm{a}$ & $8.6 \mathrm{~b}$ & $1.2 \mathrm{~b}$ \\
\hline Spring 1990 & $1.7 \mathrm{a}$ & $3.0 \mathrm{a}$ & $0.8 \mathrm{a}$ & $85.2 \mathrm{a}$ & $5.5 \mathrm{~b}$ & $0.7 \mathrm{~b}$ & $1.6 \mathrm{a}$ & $0.0 \mathrm{a}$ & $0.1 \mathrm{a}$ & $86.8 \mathrm{a}$ & $10.0 \mathrm{~b}$ & $2.1 \mathrm{c}$ \\
\hline
\end{tabular}

Means within a row and species followed by the same letter do not significantly $(P>0.05)$ according to Tukey's studentized range test. 
Table 6. Mean canopy cover (\%) of total grass, total forbs, and total herbaceous plants on 3 untreated sites (Untr) and 3 adjacent sites disced in spring 1988 (T88) or spring 1989 (T89) on La Campana Ranch, McMullen and Duval counties, Texas, summer 1988-spring 1990.

\begin{tabular}{|c|c|c|c|c|c|c|c|c|c|}
\hline \multirow[b]{2}{*}{ Season } & \multicolumn{3}{|c|}{ Total grass } & \multicolumn{3}{|c|}{ Total forbs } & \multicolumn{3}{|c|}{ Total herbaceous } \\
\hline & Untr & T88 & T89 & Untr & T88 & T89 & Untr & T88 & T89 \\
\hline Summer 1988 & $8.0 \mathrm{a}$ & $0.5 \mathrm{a}$ & - & $1.3 \mathrm{a}$ & $\begin{array}{c}-\%-- \\
0.0 \mathrm{a}\end{array}$ & - & $9.3 \mathrm{a}$ & $0.5 \mathrm{a}$ & - \\
\hline Fall 1988 & $12.2 \mathrm{a}$ & $5.0 \mathrm{a}$ & - & $1.6 \mathrm{a}$ & $4.1 \mathrm{a}$ & 一 & $13.8 \mathrm{a}$ & $9.1 \mathrm{a}$ & - \\
\hline Winter 1989 & $12.6 \mathrm{a}$ & $5.2 \mathrm{a}$ & - & $23.0 \mathrm{a}$ & $9.7 \mathrm{a}$ & 一 & $35.6 \mathrm{a}$ & $14.9 \mathrm{~b}$ & 一 \\
\hline Spring 1989 & $14.9 \mathrm{a}$ & $6.8 b$ & - & $0.9 b$ & $8.8 \mathrm{a}$ & - & $15.8 \mathrm{a}$ & $15.5 \mathrm{a}$ & - \\
\hline Summer 1989 & $17.8 \mathrm{a}$ & $8.1 \mathrm{ab}$ & $0.3 b$ & $0.2 \mathrm{~b}$ & $6.3 \mathrm{a}$ & $0.5 a$ & $18.0 \mathrm{a}$ & $14.4 \mathrm{ab}$ & $0.8 b$ \\
\hline Fall 1989 & $4.3 \mathrm{a}$ & $4.4 \mathrm{a}$ & $0.4 \mathrm{a}$ & $2.8 \mathrm{a}$ & $3.5 \mathrm{a}$ & $0.9 \mathrm{a}$ & $7.1 \mathrm{a}$ & $7.9 \mathrm{a}$ & $1.3 b$ \\
\hline Winter 1990 & $3.8 \mathrm{a}$ & $3.7 \mathrm{a}$ & $0.2 b$ & $70.0 \mathrm{a}$ & $67.1 \mathrm{a}$ & $25.7 b$ & $73.7 a$ & $70.8 \mathrm{a}$ & $25.9 \mathrm{~b}$ \\
\hline Spring 1990 & $7.3 \mathrm{a}$ & $3.8 \mathrm{a}$ & $2,1 \mathrm{a}$ & $79.1 \mathrm{a}$ & $103.6 \mathrm{a}$ & $62.2 \mathrm{a}$ & $86.4 a$ & $107.4 \mathrm{a}$ & $64.3 a$ \\
\hline
\end{tabular}

Means within a row and plant class followed by the same letter do not significantly $(P>0.05)$ according to Tukey's studentized range test.

immediately following treatment. Forb richness was higher in the 1988 treatment than the untreated in fall 1988 , and spring, summer, and fall 1989.

Poor total herbaceous response in the present study can probably be attributed to lack of rainfall. Grass and forb canopy cover after each year of discing reached similar levels as the untreated only after above-average rainfall in early spring 1990 , as observed after roller chopping. These findings agree with those of Scifres and Polk (1974), that increases in herbaceous vegetation following brush canopy removal may occur only in "wet" years.

\section{Conclusions}

Roller chopping dense brush stands dominated by guajillo and blackbrush acacia increased canopy cover of forbs preferred by white-tailed deer when rainfall was adequate. In contrast to our predictions, discing did not increase total herbaceous plant canopy cover. Lack of increase in herbaceous cover probably resulted because of low rainfall and considerable soil disturbance which left few residual plants. Response of herbaceous plants was only recorded for 2 years following treatment and increases in herbaceous cover may occur in the future because brush canopy cover remained much lower in treated than in untreated areas.

Because herbaceous response to brush removal treatments may depend greatly on rainfall, factors other than brush response may need to be considered when planning brush management strategies. Applying top-removal strategies, such as roller chopping, to dense guajillo-blackbrush acacia sites can increase availability and nutritional quality (Box and Powell 1965, Powell and Box 1966, Everitt 1983) of woody plants for browsing herbivores. Heavy discing of dense whitebrush sites can reduce whitebrush, which has little value as browse for white-tailed deer (Nelle 1984), while maintaining cover of important browse plants such as spiny hackberry.

\section{Literature Cited}

Arnold, L.A., Jr., and D.L. Drawe. 1979. Seasonal food habits of whitetailed deer in the south Texas plains. J. Range Manage. 32:175-178.

Bartz, A.E. 1981. Basic statistical concepts, 2nd ed. Burgess Publ. Co., Minneapolis, Minn.

Box, T.W., and J. Powell. 1965. Brush management for improved forage values in south Texas. Trans. North Amer. Wildl. Conf. 30:285-296.

Buckner, J.L., and J.L. Landers. 1979. Fire and disking effects on herbaceous food plants and seed supplies. J. Wildl. Manage. 43:807-811.

Canfield, R. 1941. Application of line interception in sampling range vegetation. J. Forest. 39:388-394.

Chambers, J.C., and R.W. Brown. 1983. Methods for vegetation sampling and analysis on revegetated mined lands. Gen. Tech. Rep. INT-15I. USDA, Forest Serv., Intermountain Forest and Range Exp. Sta., Ogden, Utah.
Chamrad, A.D., and T.W. Box. 1968. Food habits of white-tailed deer in south Texas. J. Range Manage. 21:158-164.

Daubenmire, R.F. 1959. A canopy coverage method of vegetation analysis. Northwest Sci. 33:43-64.

Doerr, T.B., M.C. Landin, and C.O. Martin. 1986. Mechanical site preparation techniques. Section 5.7.1, US Army Corps of Eng. Wildl. Resour. Manage. Manual. Tech. Rep. EL-86-17, US Army Waterways Exp. Sta., Vicksburg, Miss.

Drawe, D.L. 1977. A study of five methods of mechanical brush control in south Texas. Rangeman's J. 4:37-39.

Everitt, J.H. 1983. Effects of shredding on nutrient content of four south Texas deer browse species. J. Range Manage. 36:779-781.

Fulbright, T.E., and S.L. Beasom. 1987. Long-term effects of mechanical treatments on white-tailed deer browse. Wildl. Soc. Bull. 15:560-564.

Gould, F.W. 1975. Texas plants-a checklist and ecological summary. Tex. Agr. Ext. Serv. Misc. Pub. 585/Rev.

Guthery, F.S. 1986. Beef, brush and bobwhites. Caesar Kleberg Wildl. Res. Inst. Press, Kingsville, Tex.

Graham, M.W. 1982. Diets of white-tailed deer and nilgai antelope in south Texas. M.S. Thesis, Texas A \& I Univ., Kingsville.

Minzenmayer, F.E. 1979. Soil survey of Jim Wells County, Texas. USDA, SCS, U.S. Gov. Print. Off., Washington, D.C.

Montemayor, E., T.E. Fulbright, L.W. Brothers, B.J. Schat, and D. Cassels. 1991. Long-term effects of rangeland disking on white-tailed deer browse in south Texas. J. Range Manage. 44:246-248.

Naderman, J.F. 1979. Deer use of different size mechanically cleared openings in south Texas brush. M.S. Thesis, Texas Tech Univ., Lubbock.

National Fibers Information Center. 1987. The climate of Texas counties. Univ. Tex., Austin and Texas A \& M Univ., College Station.

Nelle, S. 1984. Key food plants for deer-south Texas, p. 281-291. In: L.D. White and D. Guynn (eds). Proc. 1984 Internat. Rancher's Roundup. Tex. Agr. Res. and Ext. Serv., Uvalde.

Nurdin, and T.E. Fulbright. 1988. Disking of improved rangeland to increase wildlife food plants. Tex. J. Agr. Natur. Resour. 2:32-34.

Pielou, E.C. 1977. Mathematical ecology. John Wiley \& Sons, New York, N.Y.

Powell, J., and T.W. Box. 1966. Brush management influences preference values of south Texas woody species for deer and cattle. J. Range Manage. 19:212-214.

Powell, J., and T.W. Box. 1967. Mechanical control and fertilization as brush management practices affect forage production in south Texas. $J$. Range Manage. 20:227-236.

Reynolds, J.P., T.E. Fulbright, and S.L. Beasom. 1989. Effects of roller chopping on nutritional quality of guajillo and blackbrush, Abstr. 054. Proc. 42nd Annual Meeting, Soc. Range Manage.

Rolins, D. 1983. Wild life response to different intensities of brush removal on the Edwards Plateau of Texas. Ph.D. Thesis, Texas Tech Univ. Microfilms, Ann Arbor, Mich. (Diss. Abstr. Int. 44:2299).

Scifres, C.J. 1980. Brush management-principles and practices for Texas and the Southwest. Tex. A \& M Univ. Press, College Station.

Scifres, C.J., J.L. Mutz, and G.P. Durham. 1976. Range improvement following chaining of south Texas mixed brush. J. Range Manage. 29:418-421.

Scifres, C.J., and D.B. Polk, Jr. 1974. Vegetation response following spraying a light infestation of honey mesquite. J. Range Manage. $27: 462-465$ 
Soil Conservation Service. 1985. General soil map of MacMullen County, Texas. USDA, SCS, Temple, Tex.

Steuter, A.A., and H.A. Wright. 1980. White-tailed deer densities and brush cover on the Rio Grande Plain. J. Range Manage. 33:328-330.

Varner, L.W., and L.H. Blankenship. 1987. Southern Texas shrubsnutritive value and utilization by herbivores. p. 108-112. In: Proc. Symp. on Plant-Herbivore Interactions. USDA, Forest Serv. Gen. Tech. Rep. INT-222.
Webb, W.M., and F.S. Guthery. 1983. Response of wildlife food plants to
spring discing of mesquite rangeland in northwest Texas. J. Range Manage. 36:351-353. 